DOI: $10.1515 / \mathrm{abcsj}-2016-0001$

\title{
Editorial
}

\section{The Romance of Reading (in) Academic Fiction}

Two facts are generally held to be true of fictions of academia: that the genre has proliferated steadily since the beginning of the twentieth century, and that it has been largely neglected by criticism. The present volume celebrates the former fact and seeks to rectify the latter. It aims to include novels and critical responses from cultures other than the Anglo-American in which the genre was born, and aspects other than the conventional features of the campus and academic novel.1 Thus, this volume features two excerpts from novels written by a Spanish author (Max Besora) and a Romanian one (Lucian Bâgiu), each prefaced by the author's thoughts on the genre, along with an interview with American novelist Alex Kudera, author of Fight for Your Long Day (2010). Both Bâgiu and Kudera tell the stories of disaffected young instructors rather than established professors, whereas Besora draws on his student years. Like many such novels, these are tales of disillusionment, in which the hapless heroes find themselves bindered in their pursuit of knowledge and spiritual and professional fulfilment. But while Kudera's protagonist is frustrated by the need to hold down five jobs in order to survive financially, Bâgiu's experiences a sense of inadequacy because he feels that he has infiltrated academia under false pretences, as does Besora's perpetual student. The articles by Raluca Andreescu and Tammy Ho, included here, discuss further instances of such disillusionment, as does Marta Lysik's personal essay, while Elizabeth Switaj enquires into the relative paucity of teaching scenes in academic fiction, which she puts down to obstructing administration.

The readiness with which young academics resonate with the plight of the protagonists of such novels, along with the recent evolution, described by Jeffrey Williams, of campus and academic fiction towards more mainstream 
genres such as the Bildungsroman and the fiction of suburban life, respectively, would seem to warrant a more prolific critical response. The reason for its absence, Merritt Moseley suggested in a 2014 conference keynote speech that sparked the idea of the present project, is that academia is taken both too seriously and not seriously enough in real life. There is therefore a reluctance to engage such comic and satiric depictions of academic life and a suspicion that such engagement might be construed as the venting of personal frustration. These attitudes are culture-specific, as Moseley shows, and it is often the case that more critical attention is expended on academic fiction in countries in which the genre does not have a long tradition. This tendency seems to be confirmed by the nationalities and institutional affiliations of our contributors, all of whom, with the exception of Merritt Moseley, are marginal or extrinsic to the Anglo-American cultural space.

Be that as it may, many of their contributions share with the novels a nostalgia for an ideal alma mater, the seat of spiritual nourishment and personal fulfilment, as well as a microcosm of a beneficent universe. In the novels, this nostalgia often veers into satire, when it does not sour into downright caricature, dystopia or murder mystery, although usually it remains within the realistic register, where, as Williams shows, more recently it merges with literary modes which connote a wider cultural scope, becoming, particularly in its academic novel variety, "a major vehicle for middle class, adult experience" (569). Sometimes, this nostalgia ${ }^{2}$ is dramatized as a romance-like quest for the key to the examined life. A few examples of novels which are otherwise treated only marginally in this volume will illustrate what I take to be the enduring appeal of this genre.

Jim Dixon's inebriated exploits in Kingsley Amis's iconic novel Lucky Jim (1954) inaugurated staple features of academic fiction's commentary on the state of knowledge and learning in contemporary society. Telling the story of a young temporary lecturer at an unnamed provincial university, the novel revolves around the question of whether or not his contract should be renewed. The lecture on which Dixon's continuation binges is all but absent from the novel, though indications as to what it might 
have contained in design are strewn through much of the last quarter of the text. Ensconced in an idyllic and unassuming institution, where most of the staff is happy enough to perpetuate the romance of the self-sufficiency of the intellectual life, the protagonist is expected to extol the conservative values upon which his own employment depends. In execution, the lecture is a parody of the original plan, as well as of the institution that has demanded $i t$; by the end of its delivery Dixon passes out in front of his audience in culminating disdain for what they stand for. A milestone in academic fiction and advertised by Penguin as "The comic novel of our time" (front cover), Lucky Jim has come to symbolise the debunking of the ossified, out-of-touch trappings and forms of authority instantiated by academia.

Yet it does so in no unambiguous terms. As critic Peter Conradi rightly observes, by the end of the book, the protagonist gets the girl and a more lucrative position with an art collector, thereby confirming rather than challenging the romance of the self-assertive hero who prevails by remaining true to himself. The novel thus seems to propose a narrative in which though man must submit to the rigors of the exchange market, he can do so with all the scepticism of the free-thinking, self-searching rationalist and individualist. In Conradi's view, despite his self-absorbed disaffection, Jim Dixon is a "man of sentiment" and "painfully honest about the near-incapacitating child-like intensity of his feelings" (637). The critic takes this as a sign of "Waugh-like hostility to the modern world" and of nostalgia for a community characterised by "a no-nonsense bonhomie, a conspiratorial freemasonry of men ... of good sense" (637). Both the appeal of romance and this nostalgia, though at odds with the satiric tenor of much academic fiction, have remained key features of that genre.

But while in Lucky Jim such an enlightened community exists only implicitly, as aspiration, in A.S. Byatt's 1990 bestselling Possession, selfconsciously subtitled "A Romance," the nostalgia for it is acted upon on several levels. Set in the 1980s academic milieu, with its fetishisation not only of the written word but of any object associated with writing, and with its well-rehearsed scepticisms and theory-informed wrangling over meaning, 
the book centres on two disenchanted academic readers of Victorian poetry who unearth a previously unsuspected correspondence and love affair between the fictional poets Randolph Henry Ash and Christabel LaMotte. As they untangle the relevance of their discovery to the poets' biographies and works, the two scholars, Roland Mitchell and Maud Bailey, learn to face their own emotional inadequacies. Postmodernly aware of the simultaneous constructedness of plots and the "deep buman desires" for coherence and closure, Roland and Maud hesitate to recognise the situation they find themselves in as "that sort of plot," that is, a love story (Byatt, Possession 422). Despite this self-reflexive knowingness which extends from protagonists to narrative structure, Possession embraces the pleasures and satisfactions of romance. Its recreation of the Victorian Age through Roland and Maud's detective-like quest for knowledge is complete with a Dickensian discovery that Mand is descended from both Ash and LaMotte. Yet the novel resists clear-cut closure: while Roland and Mand acknowledge their love and promise to find a way to be together, there is no marriage at the end; and although, as readers discover, Ash serendipitously met his daughter by Christabel, the mother - and the scholars - never learn about their encounter.

More than a love story, Possession is a romance of reading. As the narrator admits, this is an uncommon pursuit: while writers routinely invoke other sources of pleasure, they "do not habitually elaborate on the equally intense pleasure of reading" (Byatt, Possession 470). Byatt nonetheless attempts it:

Now and then there are readings that make the hairs on the neck... stand on end and tremble, when every word burns and shines hard and clear and infinite and exact, like stones of fire, like points of stars in the dark readings when the knowledge that we shall know the writing differently or better or satisfactorily, runs abead of any capacity to say what we know, or how. In these readings, a sense that the text has appeared to be wholly new, never before seen, is followed, almost immediately, by the sense that it was 
always there, that we the readers, knew it was always there, and have always known it was as it was, though we have now for the first time recognised, become fully cognisant of, our knowledge. (Possession 471472, emphasis in the original)

This highly gratifying experience - equal shares of discovery and recognition -, the novel seems to suggest, is the upshot of the romance of academic life, the object of its quest, and it is the aim of academic fiction to replicate it. Possession is therefore not only metafictional and endlessly intertextual, but prolifically readerly, integrating readings, and the reading of readings, of no fewer than 17 fictional writers, by critics Derek. Alsop and Chris Walsh's count (164). More than any other activity, reading epitomises the pursuit of self-knowledge in this book. The quest at its heart is for letters as repositories of ever new and unsuspected truths, and reinterpretation and misinterpretation are central tropes. What is at stake, as Alsop and Walsh note, is the freedom to read (164).

The second novel of David Lodge's campus trilogy, titled Small World: An Academic Romance (1984), thematises the concern with reading in similarly nostalgic ways. The account of one young academic, Persse McGarrigle's pursuit of an elusive female colleague with whom he became infatuated at a conference, Small World shares with Possession the celebration of the pleasures of romance, especially the eventful plot, the quest, the coincidences, but also the metafictional knowingness. Its register however is very different: like Lucky Jim, it satirises an academia which encourages the proliferation of myths only to disprove their validity. Significantly, the holy grail that restores academia to health, fertility and sanity is the question, raised by the protagonist at the final conference, "What follows if everyone agrees with [any given critical position]?" (Lodge 319). As in Amis's novel, rationalism and individualism are the antidote to the stultifying wrangling for influence and star status that seems to dominate Lodge's academe; as in Byatt's novel, what is in dispute is the freedom to read. Himself an aspiring poet, well read in modern literature from 
Shakespeare to T.S. Eliot and genuinely curious about recent theories, Persse plainly does not endorse Dixon's policy of reading "as little as possible of any given book" (Amis 16). Yet whereas Possession redeems its academics by showing them to be no better and no worse than fallible bumans, Small World only reinvigorates them as if by magic to prepare them for further mischief. Evocations of romance, Lodge seems to indicate, while they have their narrative advantages, are no longer possible without a good dose of satire and self-irony.

Small World also shares with Possession an epigraph from Nathaniel Hawthorne, according to which romance "claims a certain latitude, both as to its fashion and material," and "connects a bygone time with the very present that is flitting away from us" (qtd. in Byatt, Possession n.p.). In the Author's Note, Lodge acknowledges that latitude: "Small World resembles what is sometimes called the real world, without corresponding exactly to it" (n.p.). His novel openly deploys Eliot's mythical method, "a way of ordering, of giving a shape and a significance to the immense panorama of futility and anarchy which is contemporary history" by superimposing the logic of myth - specifically, of the Fisher King myth - on contemporary events and circumstances. This association is anticipated by the fact that the novel begins by quoting the opening line of The Waste Land, having paraphrased Chaucer in its Prologue. Although by no means short on mythical patterns, Byatt's novel interprets Hawthorne's prescriptions in the direction of a sympathetic rereading of the past: it is "parodic not in a sneering or mocking way, but as 'rewriting' or 'representing' the past," the author submits in a brief note on its writing ("Choices" 17). A homage to fictionists such as George Eliot, Nathaniel Hawthorne, Henry James and Umberto Eco, Possession, too, uses intertextuality in order to enbance "the truth of the human heart" (Hawthorne qtd. in Byatt, Possession n.p.) which it propounds, specifically the importance of reading to personal development and identity.

What is conspicuously absent from these romances of reading and learning, as Switaj perceptively notes in her contribution to this volume, are 
instances of teaching and classroom interaction. Obstructed by the obtuse demands of bureaucrats or busy with their research or with the modern version of the medieval pilgrimage, the conference circuit, these academics are seldom represented in their classrooms. An interesting exception is Azar Nafisi's Reading Lolita in Tehran (2003). Subtitled "A Memoir in Books" and delivering a fictionalised version of the author's experiences in 1990s Tehran, it gives an entirely new meaning to the freedom to read, and one with which, whatever the author's politics, readers from other former dictatorships can resonate. Barred from teaching at Iranian universities for political reasons, the protagonist organises a book club/ literature class for women at her home, where western classics such as The Great Gatsby, Pride and Prejudice, Washington Square or Lolita are read as a way of putting current events into perspective. Her nostalgia for an earlier period when women had been permitted to study and teach at university is palpable. As Corina Selejan argues elsewhere, Nafisi's book is an attempt to recreate Tebran academia as what Pierre Nora has called a lieu de mémoire, a site of memory "that has barely survived in a historical age that calls out for memory because it has abandoned it" (Nora 12). It is a displaced academia, where professor and students can no longer meet in university halls and share ideas freely, but recreate the exchange of knowledge in the privacy of a home in order to "block the work of forgetting" and ensure "an unpredictable proliferation" of meaning (Nora 19). Although not strictly speaking an academic novel, Nafisi's book contributes a dimension which is often missing from the genre: by dramatizing underground classroom interaction, it points to the political dimension of reading.

Thomas Docherty has repeatedly pointed out the political investment of reading. To him, academic freedom, of which the freedom to read is the type, though commonly considered only "in terms of the questioning of received wisdom within a discipline," reaches well beyond the lecture ball. It is in fact "instrumental in determining political authority in societies. Through reasoned dialogue in which views are freely and honestly expressed, societies can establish informed democratic legitimacy" ("Academic Freedom"). This 
high-minded conception of academic freedom indicates what is in fact at stake when the freedom to read is threatened: pluralism and democracy itself. In the article excerpted above, Docherty discusses current attacks on academic freedom by a disconnected institutional management, not dissimilar to those satirised in the novels analysed in this volume by Andreescu, Lysik and Switaj. However, as Williams points out in his survey, academic fiction, even at its most panoramic, and even in the strand dramatizing the culture wars, ${ }^{3}$ remains interested in cultural politics and "politics within institutions rather than in the public sphere" (581). Don DeLillo's White Noise (1985) is symptomatic in this respect: its protagonist, Jack Gladney, is a professor of Hitler studies who is interested not in the historical deeds of the Nazi leader but only in his status as a cultural signifier in post-bistorical America. Similarly, the academic novel is typically reluctant to dwell on the systemic repercussions of the restrictions with which academia is daily confronted; the fact that a semi-fictional memoir such as Nafisi's spells them out is in that sense remedial.

Although not often politically engaged, academic fiction's treatment of contemporary culture has become increasingly complex over the past few decades. As Williams points out, while Small World is practically illegible to people outside the humanities, White Noise, published only a year later, "transforms the genre from a sideshow to an allegory of our era" (565-566). Novels such as Philip Roth's The Human Stain (2000), Jonathan Franzen's The Corrections (2001) and Zadie Smith's On Beauty (2005), in which the university is only one of several institutions of the modern world that are satirised and whose characters illustrate and debate the class, ethnic and gender diversity of postmodern society, belong to this new trend. On Beauty, perhaps more than the others, bridges the gap between representations of the insular campus and allegories of contemporary society, by bringing the culture wars into the agora and by showing academics and laypersons alike in the process of reading cultural texts as diverse as Rembrandt and Haitian paintings, Shakespeare and Spoken Word, Mozart and Mick Jagger, scholarly articles, newspapers and emails, and 
much else in between. It does all that while chronicling the loves and contretemps of two rival academics and their families, the Belseys and the Kippses, in a narrative whose form and style constitute an overt homage to, and rereading of, E.M. Forster's Howards End.

Our volume interrogates reading practices by including not only a great range of genres, from novel through interview and personal essay to the scholarly article and review, but a selection of comparative studies by scholars from diverse corners of the world and at various stages in their careers. Some of these texts, particularly Ho's and Lysik's articles, but also Bâgiu's chapter from Bestiary, seek to humanise the academic by attempting to reconcile inner needs with professional demands; others - by Drag, Selejan and Andreescu - are more formally inclined, foregrounding self-reflexivity and generic bybridity; still others analyse the relationship between academia and society, for instance Moseley's interview with Kudera, but also Andreescu's and Switaj's articles; like the novels discussed by Ho, Besora's chapter offers the student's perspective on the institutionalised exchange of knowledge. These critical and creative readings of fictions of academia aim to enact the reinvigoration and diversification of reading for which Persse Mc Garrigle calls at the end of Small World.

\section{ANA-KARINA SCHNEIDER, Lucian Blaga University of Sibiu}

\section{Notes:}

${ }^{1}$ In what follows I operate with Jeffrey Williams's useful distinction between campus novels and academic novels:

I would call the former "campus novels" because they tend to revolve around campus life and present young adult comedies or dramas, most frequently coming-of-age narratives. The latter I would designate "academic novels" because they feature those who work as academics, although the action is rarely confined to 
a campus, and they portray adult predicaments in marriage and home as well as the workplace, most familiarly yielding mid-life crisis plots. (561-562)

2 According to Fredric Jameson, nostalgia is an intrinsic part of romance, typically "nostalgia for a social order in the process of being undermined and destroyed by nascent capitalism, yet still for the moment coexisting side by side with the latter" (158). Many academic novels evince this kind of nostalgia for a more favourable time, when market forces did not dictate the fate of academia.

${ }^{3}$ Williams's survey of academic fiction written over the past few decades in the U.S. distinguishes five strands depending on whether it veers towards a more panoramic view of society than had previously been customary in campus-bound novels such as the three mentioned above, towards dramatisations of the postmodern condition or the culture wars of the 1980s and 1990s, or whether it focused more narrowly on the professor as, typically, professional middle-class white male contending with various existential crises and occasionally with deprofessionalisation. Williams's approach is "a sociology of genre, looking at the specific history and development of the academic novel and deciphering how it responds to American culture" (578).

\section{Works Cited}

Alsop, Derek and Chris Walsh. The Practice of Reading. Interpreting the Novel. Houndmills and London: Macmillan Press, 1999. Print.

Amis, Kingsley. Lucky Jim. London: Penguin Books, 1976. Print. Byatt, A.S. Possession: A Romance. London: Vintage, 1991. Print.

---. "Choices: The Writing of Possession." The Threepenny Review No. 63 (Autumn 1995): 17. Web. 15 January 2015.

Conradi, Peter. "British Fiction since 1930." Encyclopedia of Literature and Criticism. Ed. Martin Coyle, Peter Garside, Malcolm Kelsall, and John Peck. Detroit and New York: Gale Research Inc., 1991. 631-642. Print

DeLillo, Don. White Noise. New York: Viking Press, 1985. Print.

Docherty, Thomas. "On Reading." Critical Quarterly 45.3 (October 2003): 6-19. Print.

---. "Thomas Docherty on academic freedom." Times Higher Education

4 Dec. 2014. Web. 9 March 2016. 
Eliot, T.S. “Ulysses, Order and Myth.” People.Virginia.edu. N.d. Web. 27 March 2016.

Franzen, Jonathan. The Corrections. London: Fourth Estate, 2001. Print.

Jameson, Fredric. "Magical Narratives: Romance as Genre." New Literary History 7. 1 (Autumn 1975): 135-163. Print.

Lodge, David. Small World: An Academic Romance. London: Penguin, 1985. Print.

Moseley, Merritt. "East-West in Academic Fiction: An Unequal Exchange?" East-West Cultural Passage 14.1 (July 2014): 57-76. Print.

Nafisi, Azar. Reading Lolita in Tehran: A Memoir in Books. London and New York: Fourth Estate, 2004. Print.

Nora, Pierre. "Between Memory and History: Les lieux de mémoire." Representations 26, Special Issue: Memory and Counter-Memory (Spring 1989): 7-24. Print.

Roth, Philip. The Human Stain. New York: Vintage, 2001. Print.

Selejan, Corina. "Displaced Academes: Fictionalised Easts and Wests as Lieux de Mémoire." East-West Cultural Passage 14.1 (July 2014): 145-161. Print.

Smith, Zadie. On Beauty. London: Penguin, 2006. Print.

Williams, Jeffrey J. "The Rise of the Academic Novel." American Literary History 24. 3 (Fall 2012): 561-589. Web. 9 March 2016. 